\title{
ANALISIS KETERAMPILAN MENULIS SURAT RESMI MAHASISWA PGSD FKIP UNIVERSITAS RIAU
}

\author{
Rosti Idayanti, Zufriady \\ rosti.idayanti@student.unri.ac.id, zufriady@ lecturer.unri.ac.id \\ Pendidikan Guru Sekolah Dasar FKIP Universitas Riau
}

\begin{abstract}
This research is a descriptive quantitative research. The purpose of this research is to describe the skills of PGSD FKIP Riau University students in writing official letters. The data collection technique is writing test. The validity of the research has been validated by experts. The sample in this study was 78 students from the 2016 to 2018 class of PGSD FKIP Riau University students. The skills of PGSD FKIP students of the University of Riau were analyzed by using categories from 12 predetermined aspects. The results show that the average of completeness of the letter parts aspect was 94.87 with a very good category, the average of writing a letter head aspect was 69.87 with a good category, the average of the letter date aspect was 79.80 with a good category, the average number of the letter aspect was 75.32 with a good category, the average of the attachment aspect was 95.19 with a very good category, the average of things / subject aspect was 89.74 with a very good category, the average of the address letter aspect was 78.52 with a good category, the average of the greeting aspect was 75.96 with a good category, the average of the contents of the letter aspect was 90.06 with a very good category, the average of closing greetings aspect was 51.28 with a moderate category, the average of writing the name of the sender aspect was 78.20 with a good category, the average of using sentences aspect was 59.61 with a moderate category. From these results, the overall average was 78.205 with a good category. This shows that the skills of writing an official letter from PGSD FKIP Riau University students are good.
\end{abstract}

Keywords: official letter

\section{ABSTRAK}

Penelitian ini merupakan penelitian kuantitatif deskriptif. Tujuan dari penelitian ini adalah untuk mendeskripsikan keterampilan mahasiswa PGSD FKIP Universitas Riau dalam menulis surat resmi. Teknik pengumpulan data adalah tes menulis. Validitas penelitiannya telah divalidasi oleh ahli. Sampel dalam penelitian ini 78 mahasiswa dari angkatan 2016 sampai 2018 mahasiswa PGSD FKIP Universitas Riau. Keterampilan mahasiswa PGSD FKIP Universitas Riau dianalisis menggunakan kategori dari 12 aspek yang telah ditentukan. Hasilnya menunjukkan bahwa rata-rata aspek kelengkapan bagian-bagian surat adalah 94,87 dengan kategori sangat baik, rata-rata aspek penulisan kepala surat adalah 69,87 dengan kategori baik, rata-rata aspek tanggal surat adalah 79,80 dengan kategori baik, rata-rata aspek nomor surat adalah 75,32 dengan kategori baik, rata-rata aspek lampiran adalah 95,19 dengan kategori sangat baik, rata-rata aspek hal/perihal adalah 89,74 dengan kategori sangat baik, rata-rata aspek alamat surat adalah 78,52 dengan kategori baik, rata-rata aspek salam pembuka adalah 75,96 dengan kategori baik, rata-rata aspek isi surat adalah 90,06 dengan kategori sangat baik, rata-rata aspek salam penutup adalah 51,28 dengan kategori cukup/sedang, rata-rata aspek penulisan nama pengirim adalah 78,20 dengan kategori baik, rata-rata aspek penggunaan kalimat adalah 59,61 dengan kategori cukup/sedang. Dari hasil tersebut, rata-rata keseluruhan adalah 78,205 dengan kategori baik. Hal ini menunjukkan bahwa keterampilan menulis surat resmi mahasiswa PGSD FKIP Universitas Riau adalah baik.

Kata Kunci: surat resmi

\begin{tabular}{|c|c|c|}
\hline Submitted & Accepted & Published \\
\hline 03 September 2019 & 15 September 2019 & 23 September 2019 \\
\hline
\end{tabular}

\begin{tabular}{|l|c|c|c|}
\hline Citation & $:$ & $\begin{array}{c}\text { Idayanti, R \& Zufriady. (2019). Analisis Keterampilan Menulis Surat Resmi Mahasiswa PGSD FKIP Universitas Riau. } \\
\text { Jurnal PAJAR (Pendidikan dan Pengajaran), 3(5), 1162-1172. DOI: http://dx.doi.org/10.33578/pir.v3i5.7896. }\end{array}$ \\
\hline
\end{tabular}

*Copyright (C) 2019 Jurnal PAJAR (Pendidikan dan Pengajaran)

Publish by PGSD FKIP Universitas Riau, Pekanbaru, Indonesia

\section{PENDAHULUAN}

Salah satu bentuk komunikasi visual sebagai bentuk implementasi bahasa tulis adalah surat. Surat pada dasarnya dipandang sebagai salah satu sarana berkomunikasi tertulis. Surat menyurat termasuk kedalam keterampilan menulis. Keterampilan menulis dapat meningkatkan kesadaran kognitif dan linguistik (Jalil, 2001). Kontribusi keterampilan menulis dalam perguruan tinggi sebagai hal yang sangat penting. Lilis (2001) menekankan pentingnya menulis diperguruan tinggi. Hal ini sejalan dengan yang di kemukakan oleh Sujianto (1988) 
bahwa keterampilan menulis merupakan syarat yang mutlak untuk mencapai keberhasilan perkuliahan, yang selanjutnya juga merupakan kebutuhan praktis setelah nanti terjun kemasyarakat kerja.

Keterampilan menulis merupakan keterampilan ekspresif produktif melalui tulisan. Tarigan (1985) menulis merupakan kegiatan menurunkan atau melukiskan lambang-lambang bahasa yang dipahami seseorang sehingga orang lain dapat membaca lambang-lambang grafik tersebut. Menulis pada hakikatnya adalah suatu proses berpikir yang teratur, sehingga apa yang ditulis mudah dipahami oleh pembaca (Fachruddin, 1988).

Surat adalah sehelai kertas atau lebuh yang digunakan untuk mengadakan komunikasi secara tertulis (Silmi, 2006). Surat merupakan suatu sarana komunikasi yang sangat akrab dengan kehidupan kita. Surat masih digunakan sampai sekarang karena surat memiliki kelebihan dibandingkan dengan sarana komunikasi lainnya kelebihan tersebut karena surat lebih praktis, efektif dan ekonomis.

\section{KAJIAN TEORETIS Hakikat Menulis}

Pada dasarnya keterampilan menulis membutuhkan a cara presentasi pemikiran yang terstruktur dengan baik dan terencana (Braine \& Yorozu, 1998). Keterampilan menulis yang canggih adalah salah satu persyaratan dasar untuk kinerja akademik yang lebih baik serta kegiatan lain yang berkaitan dengan presentasi tulisan (Penilaian Nasional Kemajuan Pendidikan, 2002).

Menulis adalah keterampilan integratif dan proses yang penting, konstruktif, dan kompleks. Menulis, sebagai salah satu dari empat keterampilan utama, yang dipandang sebagai keterampilan yang paling penting karena perannya dalam komunikasi antara penulis dan pembaca. Menurut Tarigan (1982) menulis adalah menurunkan atau melukiskan lambang-lambang grafik yang menggambarkan suatu bahasa yang dipahami oleh seseorang sehingga orang lain dapat membaca lambang-lambang grafik.
Bagi mahasiswa PGSD FKIP Universitas Riau sebagai calon seorang guru haruslah memiliki keterampilan seperti terampil dalam hal menulis surat, karena pada dasarnya surat merupakan salah satu materi yang harus diajarkan kepada siswa. Terutama bagi mahasiswa PGSD yang nantinya akan menjadi calon guru yang memberikan pendidikan formal kepada anak-anak bangsa serta menanamkan ilmu dasar kepada anak-anak.

Penelitian mengenai surat telah banyak dilakukan pada siswa SD, SMP, dan SMA. Namun penelitian untuk Mahasiswa belum banyak dilakukan tentang surat. Berdasarkan latar belakang tersebut maka penulis tertarik melakukan penelitian dengan judul " Analisis Keterampilan Menulis Surat Resmi Mahasiswa PGSD FKIP Universitas Riau".

Berdasarkan uraian latar belakang di atas, maka penulis merumuskan masalah sebagai berikut:" Bagaimanakan keterampilan menulis surat resmi mahasiswa PGSD FKIP Universitas Riau?". Tujuan dari penelitian ini adalah untuk mendeskripsikan keterampilan menulis surat resmi mahasiswa PGSD FKIP Universitas Riau.

Menulis adalah meletakkan informasi yang dipilih berdasarkan tujuan, metode, topik, dan batas di atas kertas dengan menyusunnya melalui beberapa proses seperti memesan, mengklasifikasikan, mengasosiasikan, mencocokkan, mengkritik, memperkirakan, menganalisis, mensintesis, dan mengevaluasi (Güneş, 2007). Selanjutnya Mulyati, dkk (2005) menulis adalah menyampaikan ide atau gagasan dan pesan dengan menggunakan lambanglambang grafis (tulisan).

Menurut Kellogg (2008) menulis dapat membantu memperkuat struktur tata bahasa, meningkatkan kosa- kata, dan membantu keterampilan bahasa lainnya seperti membaca mendengarkan dan berbicara.

\section{Pengertian Surat}

Menurut Marjo (2000), surat adalah alat komunikasi tertulis, atau sarana untuk menyampaikan pemberitahuan, pertanyaan, 
permintaan, laporan, pemikiran, sanggahan dan lain sebagainya. Hal tersebut didukung oleh Triharjanto (2007) surat merupakan sehelai kertas atau lebih yang digunakan dengan mengadakan komunikasi secara tertulis. Isi surat berupa pernyataan, keterangan, pemberitahuan, laporan, permintaan, dan sebagainya. Dalam hal ini surat berfungsi sebagai sarana komunikasi yang ekonomis dan praktis.

Menurut Finoza (Anam dan Rosali, 2016) surat adalah informasi tertulis yang dapat dipergunakan sebagai alat komunikasi tulis yang dibuat dengan persyaratan tertentu. Informasi tersebut dapt berupa pemberitahuan, pertanyaan, permintaan dan laporan.

\section{Pengertian Surat Resmi}

Menurut Suparno dan Muhammad Yunus (2011) surat resmi adalah sarana komunikasi tertulis untuk menyampaikan pesan yang menyangkut kepentingan formal atau dinas. Hal ini sejalan dengan Rahardi (2008) surat dinas atau resmi adalah surat yang isinya menunjuk pada segala sesuatu yang bersifat kedinasan.

Berdasarkan pengertian diatas dapat disimpulkan bahwa surat resmi adalah surat yang memuat segala sesuatu yang berkaitan dengan tugas kedinasan yang dibuat oleh organisasi atau instansi dengan memperhatiakan aturan-aturan mengenai sistematika, isi, dan bahasa surat.

\section{Bagian-Bagian Surat}

Penulisan surat yang baik harus memenuhi bagian-bagian persyaratan sebuah surat yang telah ditentukan.

\section{1) Kepala Surat}

Kepala surat merupakan identitas singkat tentang sebuah instansi yang mengirim surat (Suprapto dalam Dalman, 2018). Penulisan kepala surat menurut Soedjito (2010) sebagai berikut:

a. Kepala surat diketik di tengah atas.

b. Lambang (logo) dicetak sebelah kiri. c. Nama Departemen dicetak pada baris pertama dengan huruf kapital semua.

d. Nama instansi dicetak pada baris kedua dengan huruf kapital dan dicetak lebih tebal dari pada nama Departemen.

e. Alamat dicetak lengkap pada baris akhir (tanpa singkatan), meliputi nama jalan, nomor kode pos, dan nomor telepon serta teleks atau faksimile (jika ada).

f. Kepala surat ditutup dengan garis tebal tunggal dan tidak ada tanda titik (.) pada akhir alamat.

\section{2) Tanggal Surat}

Menurut Suprapto (Dalman, 2018) tanggal surat menunjukkan tanggal surat tersebut dibuat. Tanggal surat berfungsi untuk mengetahui batas waktu penyelesaian masalah yang ada didalam surat. Selain itu tanggal surat juga memudahkan petugas dalam pengarsipan surat. Contoh penulisan tanggal surat : 20 Februari 2019

\section{3) Nomor Surat}

Surat resmi yang dikeluarkan harus diberi nomor surat dan kode surat. Menurut Suprapto (Dalman, 2018) nomor surat menunjukkan urutan keluarnya surat, sedangkan kode surat menunjukkan jenis isi surat.

\section{4) Lampiran}

Lampiran berguna untuk menunjukkan adanya sesuatu yang disertakan bersama surat. Sesuatu yang harus dicantumkan dengan jelas, singkat, dan lengkap, sehingga penerima surat dengan segera dapat mengetahui apakah yang dilampirkan telah sesuai dengan apa yang tertulis dalam lampiran.

\section{5) Hal/Perihal}

Hal atau perihal merupakan inti dari sebuah surat, maka hal/perihal cukup ditulis sesingkat mungkin, namun dapat dipahami dan menggunakan huruf kapital pada awal kata dan berjenis kata benda bukan kata kerja (Suprapto dalam Dalman, 2016).

\section{6) Alamat Surat}

Contoh penulisan alamat surat

Tabel 1. Contoh Penulisan Alamat Surat

\begin{tabular}{ll}
\hline \multicolumn{1}{c}{ Contoh alamat lengkap } & \multicolumn{1}{c}{ Contoh alamat tidak lengkap } \\
\hline Yth. Direktur PT Sejahtera & Yth. Direktur PT Sejahtera \\
Jalan Cempaka & Tangerang \\
Tangerang 54531 & \\
\hline
\end{tabular}




\section{7) Salam Pembuka}

Suprapto (Dalman, 2018) penulisan salam pembuka di mulai dari margin kiri, bukan di tengah-tengah dan tidak pula menjorok kedalam seperti paragraf. Rangakaian kata salam diawali dengan huruf capital dan diakhiri dengan tanda koma (,).

\section{8) Isi Surat}

Isi surat biasanya terdiri atas alinea pembuka (kata pendahuluan), alinea isi (isi sesungguhnya), dan alinea penutup (kata penutup). Alinea pembuka merupakan pengantar kepada masalah yang diberitahukan, dilaporkan, dinyatakan, diminta, atau hal-hal lain yang disampaikan oleh penulis surat ke penerima surat (Soedjito, 2010).

\section{9) Salam Penutup}

Menurut Suprapto (Dalman, 2016) salam penutup merupakan bagian surat yang ditulis setelah isi surat untuk menunjukkan ungkapan rasa penulis surat. Tempat penulisan salam

\section{METODE PENELITIAN}

Penelitian ini menggunakan jenis penelitian metode kuantitatif deskriptif. Metode kuantitatif adalah metode penelitian yang berlandaskan pada filsafat positivisme digunakan untuk meneliti pada populasi atau sampel tertentu, pengumpulan data menggunakan instrument penelitian, analisis data bersifat kuantitatif atau statistik. Menurut Suryabrata (2013) penelitian deskriptif adalah penelitian yang bermaksud untuk membuat pecandraan (deskripsi) mengenai situasi-situasi atau kejadian kejadian.

Dengan kata lain, data yang diperoleh dari hasil keterampilan menulis surat resmi pada mahasiswa PGSD FKIP Universitas Riau akan diolah dengan menggunakan angka-angka dan akan ditabulasikan dengan menggunakan rumus statistika serta penjelasan secara detail (dideskripsikan). Populasi dalam penelitian ini adalah seluruh mahasiswa PGSD FKIP Universitas Riau yang masih aktif pada semester genap tahun akademik 2018/2019. Populasi penelitian ini berjumlah 354 orang mahasiswa. penutup biasa ditulis di atas dan lurus dengan identitas pengirim surat.

\section{0) Pengirim}

Pengirim surat dinas adalah orang yang bertanggung jawab terhadap lembaga atau organisasi yang di pimpinnya. Identitas pengirim dalam surat dinas biasanya terdiri dari jabatan pengirim, tanda tangan pengirim, stempel/cap dinas, nama terang pengirim, dan keterangan lain, misalnya NIP.

\section{Bahasa dalam Surat Resmi}

Pada dasarnya, bahasa surat merupakan kunci utama dalam menulis surat. Jika keliru atau kurang teliti dalam menggunakan bahasa di dalam suratnya, maka surat tersebut tidak akan dipahami oleh pembacanya. Menurut Soedjito (Dalman, 2018) kebakuan bahasa surat meliputi ejaan, bentuk kata, pilihan kata dan kalimat. Dalam hal ini bahasa surat yang standar yaitu bahasa surat yang baku dari segi ejaan, pilihan kata, dan kalimat.

Pada penelitian ini peneliti menentukan besarnya sampel menggunakan teknik simple random sampling. Teknik simple random sampling adalah teknik pengambilan sampel dari populasi yang dilakukan secara acak tanpa memperhatikan strata yang ada dalam populasi tersebut (Sugiyono, 2013: 82). Untuk menentukan jumlah sampel dalam penelitian ini, peneliti menggunakan rumus Slovin (Riduwan: 2012) yaitu:

$n=\frac{N}{N \cdot d^{2}+1}$

Keterangan:

$\mathrm{n}=$ Jumlah Sampel

$\mathrm{N}=$ Jumlah Populasi

$\mathrm{d}^{2}=$ Presisi Sampel

Dengan mengambil tingkat presisi $10 \%$, sehingga jumlah sampel yang diambil adalah 78 mahasiswa.

Data yang digunakan dalam penelitian ini adalah data kuantitatf dan sumber data pada penelitian ini merupakan data dari kemampuan 
mahasiswa PGSD FKIP Universitas Riau dalam menulis surat resmi. Instrumen pengumpulan data yang digunakan dalam penelitian ini berupa instrumen observasi kemampuan mahasiswa PGSD FKIP Universitas Riau dalam menulis surat resmi. Teknik pengumpulan data berupa observasi hasil penulisan surat resmi oleh mahasiswa PGSD FKIP Universitas Riau dari angkatan 2016 sampai 2018 tentang undangan kegiatan Bulan Bahasa yang dilaksanakan pada tanggal 6-11 Mei 2019. Teknik analisis data menggunakan analisis deskriptif. Untuk menentukan persentase rata-rata kemampuan menulis surat resmi menggunakan rumus statistika sederhana, yaitu:

$P=\frac{F}{N} \times 100 \%$

Keterangan:

$$
\begin{aligned}
& \mathrm{P}=\text { angka persentase } \\
& \mathrm{F}=\text { jumlah frekuensi } \\
& \mathrm{N}=\text { jumlah seluruh mahasiswa }
\end{aligned}
$$

Adapun kriteria tingkat keterampilan menulis surat resmi mahasiswa berdasarkan tolak ukur penilaian nya sebagai beikut:

Tabel 2. Tolak Ukur Penilaian Surat Resmi

\begin{tabular}{cc}
\hline Skala 100 & Kategori \\
\hline $81-100$ & Sangat Baik \\
\hline $61-80$ & Baik \\
\hline $41-60$ & Cukup/ Sedang \\
\hline $21-40$ & Kurang \\
\hline $0-20$ & Sangat kurang
\end{tabular}

Sugiyono (Afrianti, 2019)

\section{HASIL DAN PEMBAHASAN}

Penelitian ini dilakukan dengan memvalidasi lembar observasi dan rubrik observasi tentang surat resmi terlebih dahulu. Setelah instrument dinyatakan valid, kemudian peneliti meminta kepada 78 mahsiswa PGSD FKIP Universitas Riau angkatan 2016 sampai angkatan 2018 sebagai sampel penelitian untuk membuat surat undangan kegiatan Bulan Bahasa yang dilaksanakan 6-11 Mei 2019 di gedung serbaguna FKIP. Kemudian surat resmi tersebut dianalisis berdasarkan penskoran, yang kemudian dikonvensikan menjadi nilai dan diklasifikasikan menjadi lima kategori yaitu sangat baik, baik, cukup/sedang, kurang, dan sangat kurang. Keterampilan mahasiswa dalam menulis surat resmi berdasarkan dua belas aspek terlihat pada tabel 3 dibawah ini:

Tabel 3. Rekapitulasi Keterampilan Mahasiswa PGSD Universitas Riau dalam Menulis Surat Resmi

\begin{tabular}{cccc}
\hline Skala 100 & Kategori & Jumlah Mahasiswa & Persentase \\
\hline $81-100$ & Sangat Baik & 37 & $47,43 \%$ \\
$61-80$ & Baik & 38 & $48,71 \%$ \\
$41-60$ & Cukup/Sedang & 3 & $3,84 \%$ \\
$21-40$ & Kurang & - & - \\
$0-20$ & Sangat Kurang & - & - \\
\hline & Jumlah & 78 & $100 \%$ \\
& Rata-Rata & 78,205 & Baik \\
\hline
\end{tabular}

Berdasarkan tabel 3 di atas, diketahui bahwa keterampilan mahasiswa dalam menulis surat resmi setelah dilakukan analisis dengan menggunakan lima kategori. Mahasiswa yang mendapatkan kategori sangat baik berjumlah 37 orang dengan persentase $47,43 \%$, mahasiswa yang mendapatkan kategori baik berjumlah 38 orang dengan persentase $48,71 \%$, mahasiswa 
yang mendapatkan kategori cukup/sedang berjumlah 3 orang dengan persentase yang diperoleh yaitu 3,84\%, dan pada kategori kurang dan sangat kurang tidak ada mahasiswa yang mendapatkan kategori tersebut. Kemudian diperoleh pula rata-rata keseluruhan keterampilan mahasiswa PGSD Universitas Riau dalam menulis surat resmi berdasarkan dua belas aspek yaitu $78,205 \%$. Berdasarkan rata-rata tersebut, menunjukkan bahwa keterampilan mahasiswa PGSD FKIP Universitas Riau dalam menulis surat resmi secara keseluruhan dalam kategori baik. Berikut ini keterampilan mahasiswa PGSD dalam menulis surat resmi dilihat dari per-aspek:

Tabel 4. Frekuensi Keterampilan Menulis Surat Resmi Dilihat dari Aspek Kelengkapan Bagian-
\begin{tabular}{cccc}
\multicolumn{4}{c}{ Bagian Surat } \\
\hline Skala 100 & Kategori & Jumlah Mahasiswa & Persentase \\
\hline $81-100$ & Sangat Baik & 65 & $83,33 \%$ \\
$61-80$ & Baik & 13 & $16,66 \%$ \\
$41-60$ & Cukup/Sedang & - & - \\
$21-40$ & Kurang & - & - \\
$0-20$ & Sangat Kurang & - & - \\
\hline \multicolumn{5}{c}{ Jumlah } & 78 & $100 \%$ \\
\hline
\end{tabular}

Berdasarkan tabel 4 di atas, diketahui bahwa mahasiswa dengan kategori sangat baik berjumlah 65 orang dengan persentase $83,33 \%$, mahasiswa dengan kategori baik berjumlah 13 orang dengan persentase 16,66 \%, mahasiswa dengan kategori cukup/sedang 0, mahasiswa dengan kategori kurang 0 , dan mahasiswa dengan kategori sangat kurang 0 . Hal ini dapat diketahui bahwa keterampilan mahasiswa PGSD FKIP Universitas Riau dalam menulis surat resmi dilihat dari aspek kelengkapan bagian-bagian memperoleh rata-rata 94,87 dengan kategori sangat baik.

Tabel 5. Frekuensi Keterampilan Menulis Surat Resmi Dilihat dari Aspek Kepala Surat

\begin{tabular}{cccc}
\hline Skala 100 & Kategori & Jumlah Mahasiswa & Persentase \\
\hline $81-100$ & Sangat Baik & 4 & $5.12 \%$ \\
$61-80$ & Baik & 54 & $69,23 \%$ \\
$41-60$ & Cukup/Sedang & 20 & $25,64 \%$ \\
$21-40$ & Kurang & - & - \\
$0-20$ & Sangat Kurang & - & - \\
\hline & Jumlah & 78 & $100 \%$ \\
\hline
\end{tabular}

Berdasarkan tabel 5 di atas, diketahui bahwa mahasiswa dengan kategori sangat baik berjumlah 4 orang dengan persentase $5,12 \%$, mahasiswa dengan kategori baik berjumlah 54 orang dengan persentase $69,23 \%$, mahasiswa dengan kategori cukup/sedang berjumlah 20 orang dengan persentase $25,64 \%$, dan tidak ada mahasiswa yang memperoleh kategori kurang dan sangat kurang. Hal ini dapat diketahui bahwa keterampilan mahasiswa PGSD FKIP Universitas Riau dalam menulis surat resmi dilihat dari aspek kepala surat memperoleh rata-rata 69,87 dengan kategori baik. 
Tabel 6. Frekuensi Keterampilan Menulis Surat Resmi Dilihat dari Aspek Tanggal Surat

\begin{tabular}{cccc}
\hline Skala 100 & Kategori & Jumlah Mahasiswa & Persentase \\
\hline $81-100$ & Sangat Baik & 43 & $55,12 \%$ \\
$61-80$ & Baik & 25 & $35,05 \%$ \\
$41-60$ & Cukup/Sedang & 1 & $1,28 \%$ \\
$21-40$ & Kurang & - & - \\
$0-20$ & Sangat Kurang & 9 & $11,53 \%$ \\
\hline \multicolumn{7}{c}{ Jumlah } & 78 & $100 \%$ \\
\hline
\end{tabular}

Berdasarkan tabel 6 di atas, dapat diketahui bahwa mahasiswa dengan kategori sangat baik berjumlah 43 orang dengan persentase $55,12 \%$, mahasiswa dengan kategori baik berjumlah 25 orang dengan persentase 35,05 $\%$, mahasiswa dengan kategori cukup/sedang berjumlah 1 orang dengan persentase $1,28 \%$, mahasiswa dengan kategori kurang 0 , dan mahasiswa dengan kategori sangat kurang berjumlah 9 orang dengan persentase $11,53 \%$. Hal ini dapat diketahui bahwa keterampilan mahasiswa PGSD FKIP Universitas Riau dalam menulis surat resmi dilihat dari aspek tanggal surat memperoleh rata-rata 79,80 dengan kategori baik.

Tabel 7. Frekuensi Keterampilan Menulis Surat Resmi Dilihat dari Aspek Nomor Surat

\begin{tabular}{cccc}
\hline Skala 100 & Kategori & Jumlah Mahasiswa & Persentase \\
\hline $81-100$ & Sangat Baik & 44 & $56,41 \%$ \\
$61-80$ & Baik & 13 & $16,66 \%$ \\
$41-60$ & Cukup/Sedang & 6 & $7,69 \%$ \\
$21-40$ & Kurang & 6 & $7,69 \%$ \\
$0-20$ & Sangat Kurang & 9 & $11,53 \%$ \\
\hline & Jumlah & $\mathbf{7 8}$ & $\mathbf{1 0 0 \%}$ \\
\hline
\end{tabular}

Berdasarkan tabel 7 di atas, dapat diketahui bahwa mahasiswa dengan kategori sangat baik berjumlah 44 orang dengan persentase $56,41 \%$, mahasiswa dengan kategori baik berjumlah 13 orang dengan persentase 16,66 $\%$, mahasiswa dengan kategori cukup/sedang berjumlah 6 orang dengan persentase 7,69\%, mahasiswa dengan kategori kurang berjumlah 6 orang dengan persentase 7,69 \%, dan mahasiswa dengan kategori sangat kurang berjumlah 9 orang dengan persentase $11,53 \%$. Hal ini dapat diketahui bahwa keterampilan mahasiswa PGSD FKIP Universitas Riau dalam menulis surat resmi dilihat dari aspek nomor surat memperoleh ratarata 75,32 dengan kategori baik.

Tabel 8. Frekuensi Keterampilan Menulis Surat Resmi Dilihat dari Aspek Lampiran Surat

\begin{tabular}{cccc}
\hline Skala 100 & Kategori & Jumlah Mahasiswa & Persentase \\
\hline $81-100$ & Sangat Baik & 63 & $80,76 \%$ \\
$61-80$ & Baik & 15 & $19,23 \%$ \\
$41-60$ & Cukup/Sedang & - & - \\
$21-40$ & Kurang & - & - \\
$0-20$ & Sangat Kurang & - & - \\
\hline \multicolumn{4}{c}{ Jumlah } \\
\hline
\end{tabular}

Berdasarkan tabel 8 di atas, dapat diketahui bahwa mahasiswa dengan kategori sangat baik berjumlah 63 orang dengan persentase $80,76 \%$, mahasiswa dengan kategori baik berjumlah 15 orang dengan persentase 19,23
$\%$, mahasiswa dengan kategori cukup/sedang 0 , mahasiswa dengan kategori kurang 0 , dan mahasiswa dengan kategori sangat kurang 0 . Hal ini dapat diketahui bahwa keterampilan mahasiswa PGSD FKIP Universitas Riau dalam 
menulis surat resmi dilihat dari aspek lampiran memperoleh rata-rata 95,19 dengan kategori

sangat baik.

Tabel 9. Frekuensi Keterampilan Menulis Surat Resmi Dilihat dari Aspek Hal/Perihal Surat

\begin{tabular}{cccc}
\hline Skala 100 & Kategori & Jumlah Mahasiswa & Persentase \\
\hline $81-100$ & Sangat Baik & 67 & $85,89 \%$ \\
$61-80$ & Baik & 3 & $3,84 \%$ \\
$41-60$ & Cukup/Sedang & - & - \\
$21-40$ & Kurang & 3 & $3,84 \%$ \\
$0-20$ & Sangat Kurang & 5 & $6,41 \%$ \\
\hline & Jumlah & 78 & $100 \%$ \\
\hline
\end{tabular}

Berdasarkan tabel 9 di atas, dapat diketahui bahwa mahasiswa dengan kategori sangat baik berjumlah 67 orang dengan persentase $85,89 \%$, mahasiswa dengan kategori baik berjumlah 3 orang dengan persentase 3,84 $\%$, mahasiswa dengan kategori cukup/sedang 0 , mahasiswa dengan kategori kurang berjumlah 3 orang dengan persentase $3,84 \%$, dan mahasiswa dengan kategori sangat kurang berjumlah 5 orang dengan persentase $6,41 \%$. Hal ini dapat diketahui bahwa keterampilan mahasiswa PGSD FKIP Universitas Riau dalam menulis surat resmi dilihat dari aspek hal/perihal memperoleh ratarata 89,74 dengan kategori sangat baik.

Tabel 10. Frekuensi Keterampilan Menulis Surat Resmi Dilihat dari Aspek Alamat Surat

\begin{tabular}{cccc}
\hline Skala 100 & Kategori & Jumlah Mahasiswa & Persentase \\
\hline $81-100$ & Sangat Baik & 33 & $42,30 \%$ \\
$61-80$ & Baik & 29 & $37,17 \%$ \\
$41-60$ & Cukup/Sedang & 13 & $16,66 \%$ \\
$21-40$ & Kurang & - & - \\
$0-20$ & Sangat Kurang & 3 & $3,84 \%$ \\
\hline & Jumlah & 78 & $100 \%$ \\
\hline
\end{tabular}

Berdasarkan tabel 10 di atas, dapat diketahui bahwa mahasiswa dengan kategori sangat baik berjumlah 33 orang dengan persentase $42,30 \%$, mahasiswa dengan kategori baik berjumlah 29 orang dengan persentase 37,17 $\%$, mahasiswa dengan kategori cukup/sedang berjumlah 13 orang dengan persentase $16,66 \%$, mahasiswa dengan kategori kurang 0 , dan mahasiswa dengan kategori sangat kurang berjumlah 3 orang dengan persentase $3,84 \%$. Hal ini dapat diketahui bahwa keterampilan mahasiswa PGSD FKIP Universitas Riau dalam menulis surat resmi dilihat dari aspek alamat surat memperoleh rata-rata 78,52 dengan kategori baik.

Tabel 11. Frekuensi Keterampilan Menulis Surat Resmi Dilihat dari Aspek Salam Pembuka

\begin{tabular}{cccc}
\hline Skala 100 & Kategori & Jumlah Mahasiswa & Persentase \\
\hline $81-100$ & Sangat Baik & 29 & $37,17 \%$ \\
$61-80$ & Baik & 35 & $44,87 \%$ \\
$41-60$ & Cukup/Sedang & 8 & $10,25 \%$ \\
$21-40$ & Kurang & - & - \\
$0-20$ & Sangat Kurang & 6 & $7,69 \%$ \\
\hline \multicolumn{4}{r}{} \\
\hline
\end{tabular}

Berdasarkan tabel 11 di atas, dapat diketahui bahwa mahasiswa dengan kategori sangat baik berjumlah 29 orang dengan persentase $37,17 \%$, mahasiswa dengan kategori baik berjumlah 35 orang dengan persentase 44,87 $\%$, mahasiswa dengan kategori cukup/sedang 
berjumlah 8 orang dengan persentase $10,25 \%$, mahasiswa dengan kategori kurang 0 , dan mahasiswa dengan kategori sangat kurang berjumlah 6 orang dengan persentase 7,69\%. Hal ini dapat diketahui bahwa keterampilan mahasiswa PGSD FKIP Universitas Riau dalam menulis surat resmi dilihat dari aspek salam pembuka memperoleh rata-rata 75,96 dengan kategori baik.

Tabel 12. Frekuensi Keterampilan Menulis Surat Resmi Dilihat dari Aspek Isi Surat

\begin{tabular}{cccc}
\hline Skala 100 & Kategori & Jumlah Mahasiswa & Persentase \\
\hline $81-100$ & Sangat Baik & 51 & $65,38 \%$ \\
$61-80$ & Baik & 24 & $30,76 \%$ \\
$41-60$ & Cukup/Sedang & 3 & $3,84 \%$ \\
$21-40$ & Kurang & - & - \\
$0-20$ & Sangat Kurang & - & - \\
\hline \multicolumn{4}{c}{}
\end{tabular}

Berdasarkan tabel 12 di atas, dapat diketahui bahwa mahasiswa dengan kategori sangat baik berjumlah 51 orang dengan persentase $65,38 \%$, mahasiswa dengan kategori baik berjumlah 24 orang dengan persentase 30,76 $\%$, mahasiswa dengan kategori cukup/sedang berjumlah 3 orang dengan persentase $3,84 \%$, mahasiswa dengan kategori kurang 0 , dan kategori sangat kurang 0 . Hal ini dapat diketahui bahwa keterampilan mahasiswa PGSD FKIP Universitas Riau dalam menulis surat resmi dilihat dari aspek isi surat memperoleh rata-rata 90,06 dengan kategori sangat baik

Tabel 13. Frekuensi Keterampilan Menulis Surat Resmi Dilihat dari Aspek Salam Penutup

\begin{tabular}{cccc}
\hline Skala 100 & Kategori & Jumlah Mahasiswa & Persentase \\
\hline $81-100$ & Sangat Baik & 4 & $5,12 \%$ \\
$61-80$ & Baik & 34 & $45,94 \%$ \\
$41-60$ & Cukup/Sedang & 21 & $26,92 \%$ \\
$21-40$ & Kurang & - & - \\
$0-20$ & Sangat Kurang & 19 & $24,35 \%$ \\
\hline & Jumlah & 78 & $100 \%$ \\
\hline
\end{tabular}

Berdasarkan tabel 13 di atas, dapat diketahui bahwa mahasiswa dengan kategori sangat baik berjumlah 4 orang dengan persentase $5,12 \%$, mahasiswa dengan kategori baik berjumlah 34 orang dengan persentase $45,94 \%$, mahasiswa dengan kategori cukup/sedang berjumlah 21 orang dengan persentase $26,92 \%$, mahasiswa dengan kategori kurang 0 , dan mahasiswa dengan kategori sangat kurang berjumlah 19 dengan persentase $24,35 \%$. Hal ini dapat diketahui bahwa keterampilan mahasiswa PGSD FKIP Universitas Riau dalam menulis surat resmi dilihat dari aspek salam penutup memperoleh rata-rata 51,28 dengan kategori cukup/sedang.

Tabel 14. Frekuensi Keterampilan Menulis Surat Resmi Dilihat dari Aspek Penulisan Nama Pengirim

\begin{tabular}{cccc}
\hline Skala 100 & Kategori & Jumlah Mahasiswa & Persentase \\
\hline $81-100$ & Sangat Baik & 28 & $35,89 \%$ \\
$61-80$ & Baik & 35 & $44,87 \%$ \\
$41-60$ & Cukup/Sedang & 13 & $16,66 \%$ \\
$21-40$ & Kurang & 1 & $1,28 \%$ \\
$0-20$ & Sangat Kurang & 1 & $1,28 \%$ \\
\hline & Jumlah & 78 & $100 \%$ \\
\hline
\end{tabular}


Berdasarkan tabel 14 di atas, dapat diketahui bahwa mahasiswa dengan kategori sangat baik berjumlah 28 orang dengan persentase $35,89 \%$, mahasiswa dengan kategori baik berjumlah 35 orang dengan persentase 44,87 $\%$, mahasiswa dengan kategori cukup/sedang berjumlah 13 orang dengan persentase $16,66 \%$, mahasiswa dengan kategori kurang berjumlah 1 orang dengan persentase $1,28 \%$, dan mahasiswa dengan kategori sangat kurang berjumlah 1 dengan persentase $1,28 \%$. Hal ini dapat diketahui bahwa keterampilan mahasiswa PGSD FKIP Universitas Riau dalam menulis surat resmi dilihat dari aspek penulisan nama pengirim memperoleh rata-rata 78,20 dengan kategori baik.

Tabel 15. Frekuensi Keterampilan Menulis Surat Resmi Dilihat dari Aspek Penggunaan Kalimat

\begin{tabular}{cccc}
\hline Skala 100 & Kategori & Jumlah Mahasiswa & Persentase \\
\hline $81-100$ & Sangat Baik & 5 & $6,41 \%$ \\
$61-80$ & Baik & 33 & $42,30 \%$ \\
$41-60$ & Cukup/Sedang & 28 & $35,89 \%$ \\
$21-40$ & Kurang & 12 & $15,38 \%$ \\
$0-20$ & Sangat Kurang & - & - \\
\hline \multicolumn{4}{c}{ Jumlah }
\end{tabular}

Berdasarkan tabel 15 di atas, dapat diketahui bahwa mahasiswa dengan kategori sangat baik berjumlah 5 orang dengan persentase $6,41 \%$, mahasiswa dengan kategori baik berjumlah 33 orang dengan persentase $42,30 \%$, mahasiswa dengan kategori cukup/sedang berjumlah 28 orang dengan persentase $35,89 \%$, mahasiswa dengan kategori kurang berjumlah 12 orang dengan persentase $15,38 \%$, dan mahasiswa dengan kategori sangat kurang 0 . Hal ini dapat diketahui bahwa keterampilan mahasiswa PGSD FKIP Universitas Riau dalam menulis surat resmi dilihat dari aspek penggunaan kalimat memperoleh rata-rata 59,61 dengan kategori cukup/sedang.

Dari dua belas aspek tersebut ada empat aspek yang mendapatkan kategori sangat baik yaitu aspek kelengkapan bagian-bagian surat,

\section{SIMPULAN DAN REKOMENDASI}

Berdasarkan hasil penelitian yang telah dilakukan dapat disimpulkann bahwa:

1. Secara klasikal keterampilan mahasiswa PGSD FKIP Universitas Riau dalam menulis surat resmi memperoleh kategori baik dengan rata-rata 78,205.

2. Ditinjau dari kedua belas aspek yaitu kelengkapan bagian-bagian surat, penulisan kepala surat, tanggal surat, nomor surat, lampiran, hal/perihal dan isi surat. Dari empat aspek yang mendapatkan kategori sangat baik, rata-rata nilai tertinggi per aspek yaitu ada pada aspek lampiran, dengan rata-rata 95,15. Dari ratarata yang diperoleh pada aspek lampiran, menjelaskan bahwa pada penulisan aspek lampiran mahasiswa telah menulis sesuai dengan aturan penulisan lampiran surat, yaitu apabila tidak ada yang dilampirkan di dalam surat kata lampiran tidak perlu dicantumkan. Sesuai pendapat Suparno dan Muhammad Yunus (Fauziatul: 2019) bahwa apa bila tidak ada yang dilampirkan, tulisan lampiran atau lamp. tidak perlu dicantumkan. Kalaupun dicantumkan, diberi tanda hubung (-) atau angka nol (0) sesudah tanda titik dua (:) tersebut. Oleh karena itu, semua mahasiswa menulis surat sesuai dengan aturan penulisan maka akan diberi skor 4 .

lampiran, hal/perihal, alamat surat, salam pembuka, isi surat, salam penutup, penulisan nama pengirim dan penggunaan kalimat, mahasiswa yang mendapatkan kategori sangat baik berjumlah 38 orang, mahasiswa yang mendapatkan kategori baik berjumlah 37 orang dan mahasiswa yang mendapatkan kategori cukup/sedang berjumlah 3 orang.

Berdasarkan simpulan penelitian, penulis 
akan memberikan saran kepada pihak yang berkaitan dengan penelitian. Berikut saran dari penulis:

1. Dalam penulisan surat resmi mahasiswa masih kurang terampil dalam menulis bagian surat resmi seperti kepala surat, nomor surat, salam penutup serta penggunaan kalimat. Pada umumnya kesalahan yang dilakukan mahasiswa yaitu mahasiswa kurang mengetahui penulisan kepala surat dan urutan penulisan nomor surat, mahasiswa lupa mencantumkan salam penutup serta membubuhkan tanda koma (,) pada akhir

\section{DAFTAR PUSTAKA}

Akdon. (2005). Aplikasi Statistik dan Metode Penelitian untuk Administrasi dan Managemen. Bandung: Dewa Ruchi.

Arni. (2015). Analisis Surat Dinas (Surat Undangan Resmi dan Surat SK Dosen Mengajar) Yang Dikeluarkan Tahun 2010 Oleh Lembaga STKIP-PGRI Pontianak. Jurnal Pendidikan Bahasa. 4 (1), 2. IKIP PGRI. Pontianak

Balta, E.E. (2018). The Relationships Among Writing Skills, Writing Anxiety and Metacognitive Awareness. Journal of Education and Learning. 7(3): 233.

Dalman. (2018). Keterampilan Menulis. Jakarta: Raja Grafindo.

Husni, F. (2019). Analisis Keterampilan Menulis Surat Resmi Mahasiswa PGSD Universitas Riau. FKIP Universitas Riau. Pekanbaru.

Javed, M, et, all. (2013). A Study of Students Assesment In Writing Skill of the English Language. Journal of Instruction, 6(2), 130.

Kemal, I. (2013). Keterampilan Menulis Surat Dinas. Jurnal Pendidikan Bahasa, Sastra Indonesia dan Daerah, 1(1): 2. STKIP Bina Bangsa Getsempena. Banda Aceh.

Kurniaman, O, dkk. (2017). Kemampuan Mahasasiswa PGSD FKIP Universitas Riau dalam Menulis Surat Resmi. Primary: Pendidikan Guru Sekolah Dasar, 6(1), 21. salam penutup. Sedangkan dalam penggunaan kalimat masih banya yang rancu pada kalimat yang digunakan. Oleh karena itu, mahasiswa perlu banyak belajar mengenai penulisan surat yang baik dan benar.

2. Secara keseluruhan dalam penulisan surat mahasiswa berada dalam kategori baik. Jadi sebaiknya mahasiswa perlu banyak belajar serta mempelajari tentang bagaimana penulisan surat yang baik dan benar. Tidak hanya saat ini, pasti dimasa yang akan datang kita pasti membutuhkan pengetahuan tentang menulis surat resmi.

Marjo. (2000). Surat-surat Lengkap (complete letters). Jakarta: Setia Kawan.

Muglabeh, A. I. et, all. (2019). Employing TBL and 3PS Learning Approaches to Improve Writing Skills Among Saudi EFL Students in Jouf University. Jurnal of Linguistik, Literature and Translation, 2(1), 218.

Rahardi, R.K. (2009). Aturan Pemuatan dan Pemakaian Bahasa Surat Dinas. Yogyakarta: Pustaka Book Publisher.

Soedjito \& Solchan, TW. (1994). SuratMenyurat Resmi Bahasa Indonesia. Bandung: Remaja Rosdakarya.

Suparno, Yunus, M. (2011). Keterampilan Dasar Menulis. Jakarta: UT.

Suryabrata, S. (2013). Metodelogi Penelitian. Jakarta: PT Raja Grafindo Persada.

Waskita, D. (2008) Differences In Men's And Women's ESL Academic Writing At The University of Melbourne, Jurnal Sosioteknologi, 452.

Yulianto, E. (2016). Kesalahan Penulisan Tata Bahasa Pada Surat Resmi Organisasi Mahasiswa. Jurnal Pendidikan Bahasa dan Sastra Indonesia. 08 (03), 239. Universitas Indraprasta PGRI. Jakarta.

Yuni, E.P. et, all. (2017). The Linguistic Problems Of Students Competence In Writing Business Letters. Journal of Language and Literature, 11(2), 118. 